\title{
Performance of Foreign Banks Operating in Kosovo - ProCredit Bank Kosovo - Raiffeisen Bank Kosovo \& NLB Prishtina
}

PhD. Candiate Arta Hoti

Teaching assistant in University of Prishtina "Hasan Prishtina", Kosovo, arta_h@hotmail.com

\author{
PhD. Candiate Sevdie Alshiqi - Bekteshi
}

Teaching assistant in University of Prishtina "Hasan Prishtina”, Kosovo, sevda.alshiqi@gmail.com

\author{
PhD. Candiate Besnik Livoreka
}

Teaching assistant in University of Prishtina "Hasan Prishtina”, Kosovo, besniklivoreka@gmail.com

\section{Doi:10.5901/ajis.2014.v3n2p57}

\section{Abstract}

In this paper we analysed the indicators of performance of banks with foreign capital operating in Kosovo. According to many theses of different authors worldwide, more accurate measurement of bank performance is based on application of main financial coefficients of banks such as: Return on Assets - ROA, Return on Equity - ROE and Cost/Income Ratio - C/l. This thesis describes the analyses of financial indicators for 2006-2007-2008-2009-2010-2011 and 2012 periods. The thesis contents five parts (chapters), the second part provides a literature review on the performance of banks in other countries. Third part provides a general analysis of the banking sector in Kosovo. Fourth part presents the results of financial coefficients analyzed. While fifth part presents financial analysis and provides the main conclusions. As sample for realizing this thesis are obtained the financial coefficients of three main commercial banks in Kosovo with foreign capital shareholders: Procredit Bank (former -MEB - Micro Enterprise Bank), Raiffeisen Bank (former - American Bank of Kosova) and Nova Ljublanska Banka, NLB Prishtina (established with the acquisition of two earlier banks Kasa Banka and New Bank of Kosova-BRK).

Keywords: ROA-Return on Assets, ROE-Return on Equity, C/I-Cost/Income Ratio, performance, profit-flow.

\section{Introduction}

In Republic of Kosovo operates in total nine commercial banks, eleven insurance companies, two pension funds, nineteen microfinance institutions, twenty one currency exchange offices and five money transfer agencies. (Luboteni, 2013).

From the total number of commercial banks in Kosovo, seven of them are with foreign-owned capital and only two of them are local banks, with domestic capital. Major changes in banking system in Kosovo have come as a result of the entry of foreign banks, and as a result of the global financial crisis of year 2008. These crises may have affected on banks' lending quality and in performance of the banking sector in Kosovo.

Stability and liquidity of one bank, among others, depends mainly on credit, in reality lending. The main risks facing the banking system are: credit risk, interest rate risk, foreign exchange risk, operational risk, etc.

\section{Banking Sector in Republic of Kosovo}

Regarding Kosovo banking market, it continues to be characterized by a relatively high degree of concentration, although the continuous growth of activity of small banks has affected the degree of concentration to follow the downward trend in recent years. Regarding to banking risk in Kosovo, we may note that all of services that are performed by commercial banks, credit services are the most risk exposed services.

Kosovo's banking sector consists in commercial banks activity. During the analyzed period, the number of banks has increased gradually. In 2013 the number of banks has reached in nine, which are: Procredit Bank (former MEB Micro Enterprise Bank), Raiffeisen Bank (former - American Bank of Kosova), Bank for Business (former - Private Bank 
For Business), Nova Ljublanska Banka (NLB) Prishtina (established with the acquisition of two earlier banks Kasa Banka and New Bank of Kosova (BRK)), Banka Ekonomike, Banka Kombëtare Tregtare Kosovo's Branch (BKT), Turk Ekonomi Bankasi (TEB), Ishbank and one branch of Komercijalna Banka A.D. from Belgrade that has its activity in Mitrovica (North side) and in Gracanica.

Lending still remains their main activity, as it should be considered the fact that the demand for money in a country in transition is significantly larger than the money supply, so the importance of lending remains high.

As big advantage of the banking system in Kosovo is that as the main sources of funding of the banking sector are deposits and domestic borrowings, which represent about $70-80 \%$ of all liabilities. This is the advantage that they are not tied directly to international financial markets and this has contributed to reducing the impact of global financial crisis.

\section{Variables Analysed}

\subsection{Analysis of the main coefficients of profitability (performance)}

Based on numerous works of different authors, as base for measuring the performance of commercial banks in Kosovo are taking coefficients of profitability (profit-flow) that are:

Return on Assets (ROA) - net profittotal assets.

Return on Equity (ROE) - net profit/total equity.

Cost/Income Ratio (C/I) - total cost/total income.

In this thesis are analysed the coefficients of profitability of three commercial banks in Kosovo, which have foreign equity, such as: Procredit Bank (former - MEB - Micro Enterprise Bank), Raiffeisen Bank (former - American Bank of Kosova) and Nova Ljublanska Banka (NLB) Prishtina (established with the acquisition of two earlier banks Kasa Bank and New Bank of Kosova (BRK)).

\section{Analysis of Results}

\subsection{Analysis of ROA, ROE and $\mathrm{C} / \mathrm{I}$}

The main profitability indicators are taken by the financial statements published on web-sites of each commercial bank in Kosovo, by which are calculated the percents. The values of these indicators, we may not say that they are manipulated values since each published bank financial statement, were previously audited by external auditing companies, and the risk of manipulation may be considered at $0 \%$.

According to the surveys made by auditing companies, the loans lent with high margins to the clients who seem to be of high risk, may arise the profits (in short-terms), but this also raises the bank credit risk, and also the losses in the future.

In the table 1 are shown the coefficients that measure the profitability in the banking sector of Kosovo, during 20062012 periods, including three major banks in Kosovo. The coefficients are: ROA, ROE and (C/I).

Table 1: Profitability trend during 2006-2012 periods (\%)

\begin{tabular}{|l|c|c|c|c|c|c|c|}
\hline Years & 2006 & 2007 & 2008 & 2009 & 2010 & 2011 & 2012 \\
\hline Average ROA & 1.90 & 2.40 & 2.40 & 2.00 & 1.80 & 1.70 & 1.70 \\
\hline Average ROE & 21.40 & 24.90 & 24.10 & 18.10 & 17.60 & 14.90 & 14.70 \\
\hline Average C/I & 55.3 & 76 & 78.8 & 57.3 & 80.3 & 81.6 & 80.7 \\
\hline
\end{tabular}

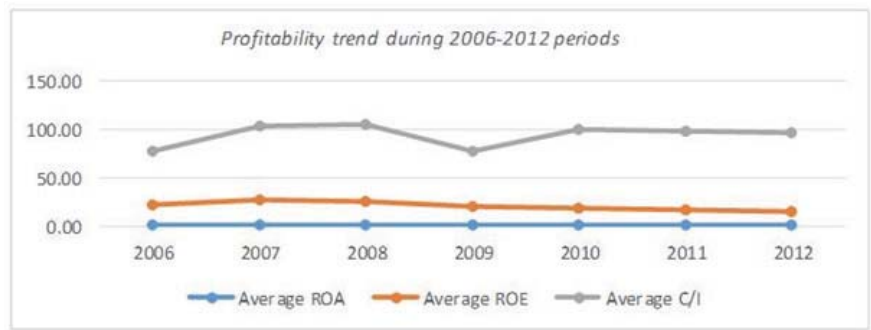

Figure 1: Profitability trend during 2006-2012 periods 
In the figure 1 it is seen a growth in the profitability trend from 2006 to 2007. ROA coefficient has increased from 1.9\% to $2.4 \%$, while during 2008-2012 it continued decreasing by a slower trend, getting to $1.7 \%$ in 2012. ROE increased from $21.4 \%$ to $24.9 \%$, while during $2008-2012$ continued decreasing by a slower trend getting to $14.7 \%$ in 2012 . Regarding to the cost/income ratio, there is seen a growth trend from 2006 to 2007. C/I coefficient increased from $55.3 \%$ to $76 \%$, and during 2008-2012 continued this increasing trend where in 2012 reaches up to $80.7 \%$.

\subsection{Analysis 2006-2007-2008-2009-2010-2011-2012}

The realized profit by commercial banks comes as a result of reducing the mediatory activity of the banking sector during the 2008-2009 periods. The year 2006 recorded not a very high decrease of ROA coefficient, see figure 2. Compared to 2006, only in 2007 there were shown an increase of this coefficient, while all the following years recorded decrease of net profit in banking sector. The profits reduce in banking sector represents negative implications for the efficiency level of this sector. In this case it may be interpreted that the average return on assets (ROA) for years 2009, 2010, 2011 and 2012 decreased compared to the previous period, thus reflecting as a lower efficiency of the three major banks during this period in realising profit by the use of available assets.

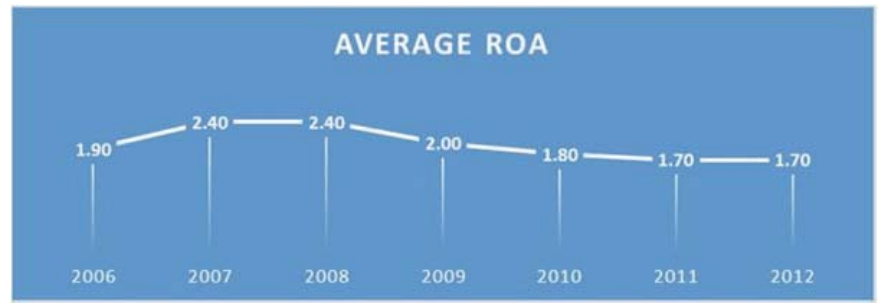

Figure 2: ROA coefficient trend

As a result of decreased profit, the profitability reduction appears in Figure 3, the three major banks in Kosovo, which is expressed through the ROE indicator. For 2009, ROE indicator declined significantly compared to previous years. The main contributor to the profit decline was slowing the flow of interest income.

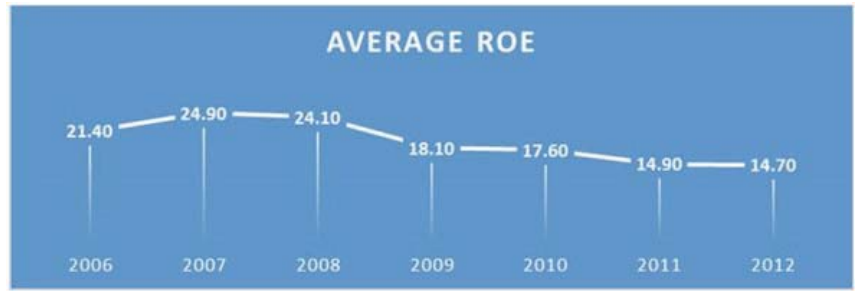

Figure 3: ROE coefficient trend

The quick growth of costs compared to total incomes of banking system, affected in reduction of net profit. This can be explained by the trend of costs to income $(\mathrm{C} / \mathrm{l})$ presented in Figure 4 . Here there is a significant increase in the trend of this coefficient in 2007 compared to 2006, while the constant increase is seen from 2010 to 2012. This ratio has been $57.3 \%$ in 2009 and it is over $80 \%$ in 2012.

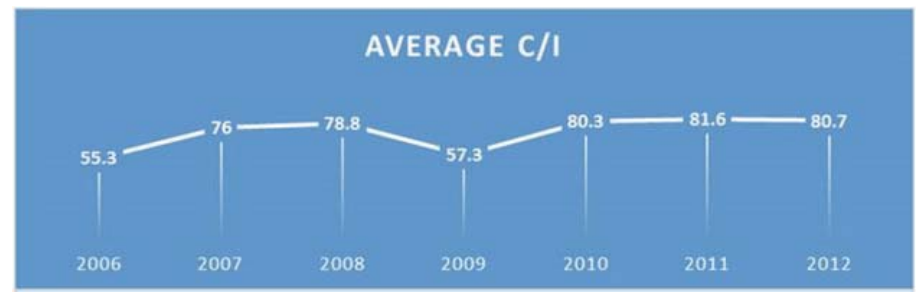

Figure 4: C/l coefficient trend 


\subsection{Analysis of profitability of ProCredit Holding - PCH for 2006-2012 periods}

Figure 5 shows an increase in the trend of profitability from 2006 to 2009. ROA coefficient of this bank increased from $1.7 \%$ to $3.0 \%$, while during $2010-2011$ continued to fall at a slower trend, reaching $2.2 \%$ in 2012 . ROE increased from $29.9 \%$ to $39.2 \%$ in 2007 , while during $2008-2012$ continued to fall at a slower trend, reaching $19.5 \%$ in 2012 . Regarding cost/income ratio, the trend shows a decline from 2006 to 2007. In 2008 we have again an increasing trend during 2009, and continues a downward trend to $77.4 \%$, not much difference from previous years.

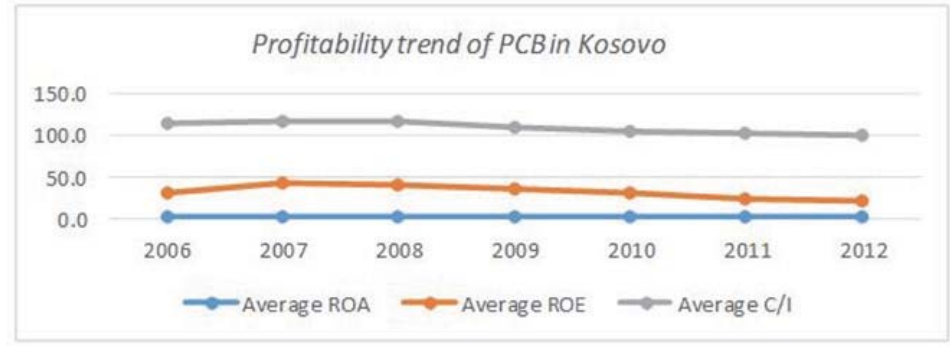

Figure 5: Profitability trend of PCB in Kosovo

\subsection{Analysis of profitability at Raiffeisen Bank International - RBI for 2006-2012 periods}

In figure 6 there is seen an increase trend of profitability from 2006 to 2007. ROA coefficient of this bank has increased from $2.8 \%$ to $3.1 \%$, while during 2009-2012 it has continued decreasing significantly, reaching up to $1.9 \%$ in 2012 . Compared to 2006, in 2007 ROE increased from $24.2 \%$ to 25.7\%, while during 2008-2012 continued with a significant decrease trend reaching $9.8 \%$ in 2009 , and afterwards went on with a slow growth reaching $13.5 \%$ in 2012 . Regarding to cost/income ratio, there is seen a decreasing trend from 2006 to 2007.

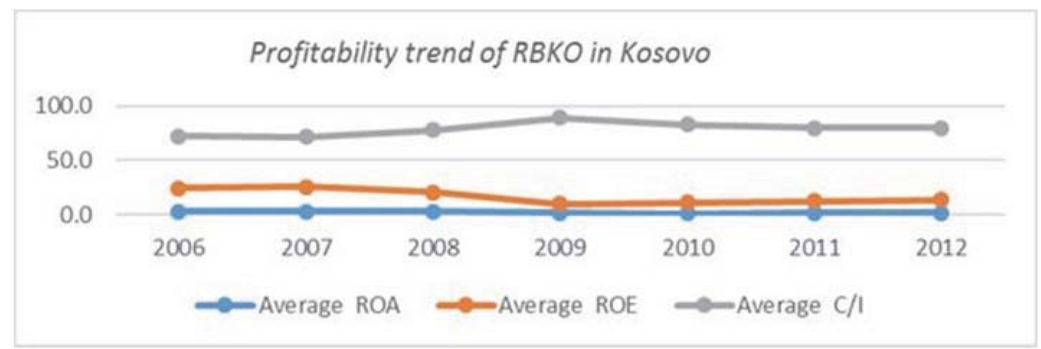

Figure 6: Profitability trend of RBKO in Kosovo

\subsection{Analysis of profitability at NLB - Group for 2006-2012 periods}

In figure 7 there is seen a decreasing trend of profitability from 2006 to 2007. ROA coefficient of this bank experienced decrease from 1.3\% to 1.1\%, while in 2008 it increased to 1.5\%. Also, a slow decrease trend is seen during 2009-2012, where in 2012 the ROA coefficient used to be 1.1\%, during 2009-2012 it continuously reflected a decrease trend where in 2012 reaches to $11.1 \%$. ROE compared to 2006 suffered a decreasing trend from $10.1 \%$ to $9.9 \%$ in 2007. Only in 2008 there were an increase of this coefficient where the trend reaches to $14.9 \%$, and afterwards during 2009-2012 it continued with a significant decrease trend reaching up to $11.1 \%$ in 2012. Regarding to costlincome ratio, an increasing trend was noticed from 2006 to 2012. 


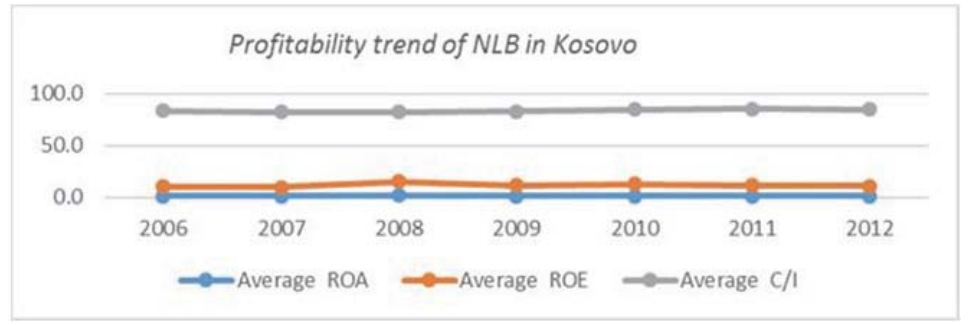

Figure 7: Profitability trend of NLB in Kosovo

\section{Summary and Conclusions}

The main aim of this thesis was as follows:

Analysis of financial indicators in the performance of the three banks operating with foreign equity in Kosovo, including the 2006, 2007, 2008, 2009, 2010, 2011 and 2012 periods.

Thus, in this thesis we realised to measure the quality of the financial indicators of profitability of the commercial banks in the banking sector in Kosovo, such as: Procredit Bank, Raiffeisen Bank and Nova Ljublanska Banka during 2006-2012 periods.

The results showed that in general, the profitability results have been on-going improvement from 2006 until 2008, while from 2008 they started declining.

According to the financial analysis made for 2006-2012 periods, we may conclude that there was not any significant change in the statistical aspect in the general performance of these three banks, including the measuring of determinants taken into consideration.

It may be concluded that these three major banks of banking sector in Kosovo have remained stable, although the profitability trend is going on a descending way.

Regarding to their between comparisons, considering the profitable financial coefficients, we may conclude that the bank that have performed in a better way during the compared period is Procredit Bank. This bank according to the profitability trend compared to Raiffeisen Bank and Nova Ljublanska Banka results to be much more profitable.

Pas Procredit Bank leads the ranging, followed by Raiffeisen Bank and the third bank in the performance level is Nova Ljublanska Banka.

In the basic level, the measurement of the banks' performance may help on the improvement of managerial performance, identifying the best and worst practices of low and high efficiency.

All at the end, the results showed that the tested commercial banks are relatively less profitable (not a significant change) compared to the previous years, and they are more exposed to the credit risk, which is considered the greatest risk of banking sector in Kosovo.

\section{References}

Prof. Dr. Luboteni, Banks and Business Banking, Pristina, 2013.

Statistical Bulletin no. 10, Central Bank of Kosovo, 2010

Report of the Financial Stability no. 10, 1,2,3, Central Bank of Kosovo (2011, 2012

Annual reports of Commercial Banks of Kosovo for the period 2006-2012.

Statistics of Foreign Trade, Economic Statistics (series 3, ASK, 2013)..

Grigorian, David A., and Vlad Manole. Determinants of commercial bank perfomance in transition: An application of data envelopment analysis. No. 2002-2146. International Monetary Fund, 2002.

Oral, Muhittin, and Reha Yolalan."An empirical study on measuring operating efficiency and profitability of bank branches."European Journal of Operational Research 46.3 (1990): 282-294.

Bonin, John P. ,Iftekhar Hasan, and Paul Wachtel."Bank perfomance, efficiency and ownership in transition countries."Journal of Banking \& Finance 29.1 (2005): 31-53

Demirguc-Kunt,Ash,and Harry Huizinga."Determinants of commercial bank interest margins and profitability:Some international evidence."The World Bank Economic Review 13.2(1999):379-408.

Cukierman, Alex, Steven B. Web,and Bilin Neyapti. "Measuring the independence of central banks and its effect on policy outcomes."The World Bank Economic Reviw 6.3(1992): 353-398. 
Beaver, William H."Financial ratios as predictors of failure. "Journal of accounting research (1966): 71-111

Malami M. Maishanu (2004:76):"A univariate Approach to Predicting failure in the Commercial Banking Sub-Sector" in Nigerian Journal of Accounting Research,Volume 1, No. 1.

Ncube,M.(2009).Efficiency of the Banking Sector in South Africa ,African Economic Conference 2009 Fostering Development in an Era of Financial and Economic Crises,Addis Ababa.

Berger, A.N and Humphrey, D.B (1997). Efficiency of financial institutions: international survey and directions for future research. European Journal of Operational Research, Vol 98, pp. 175-212.

Casu, B., Molyneux, P. And Girardone, C. (2006). Introduction to Banking, Prentice Hall/Financial Times, London.

Altman, Edward I. "Financial ratios, disciminant analysis and the prediction of corporate bankruptcy. "The journal of finance 23.4 (1986): 589-609.

Lonneke Mous(2005): Predicting bankruptcy with discriminant analysis and decision tree using financial ratios, University of Rotterdam. wWw.CAMELS rating system.com 